\title{
THE ANTIBACTERIAL POTENTIAL OF N-ACETYLCYSTEINE AS AN ENDODONTIC IRRIGANT ON THE CLINICAL ISOLATES OF THE ENTEROCOCCUS FAECALIS BIOFILM
}

\author{
RIDZKI RIDHALAKSANI, KAMIZAR NAZAR*, NILA KESUMA DJAUHARIE, RATNA MEIDYAWATI, DEWA AYU NPA
}

Department of Conservative Dentistry, Faculty of Dentistry, Universitas Indonesia, Jakarta, Indonesia. Email: kamizar_kz@yahoo.com

Received: 16 September 2017, Received and Accepted: 01 December 2017

ABSTRACT

Objective: The aim of this study was to evaluate the antibacterial potential of NAC as an endodontic irrigant on the clinical isolates of the Enterococcus faecalis biofilm.

Methods: NAC with a pH of 2.5 and 11 (NAC pH 2.5 and NAC pH 11, respectively) were exposed to clinical isolates of $E$. faecalis biofilms for 1 min. The NAC samples were compared to $2 \%$ chlorhexidine (CHX), which is commonly used as an irrigant in persistent infections. The antibacterial potential of these irrigants was evaluated by comparing the bacterial count of the E. faecalis colonies after they were exposed to the irrigants.

Results: The NAC pH 2.5 test group showed a reduction in the E. faecalis colonies, but this reduction was not statistically significant when compared to the $2 \%$ CHX group results. The NAC pH 11 test group showed the greatest reduction in bacterial colonies, and this reduction was statistically significant when compared to the NAC pH 2.5 and $2 \%$ CHX groups' results.

Conclusion: NAC pH 11 has antibacterial potential on the clinical isolates of E. faecalis biofilms.

Keywords: Enterococcus faecalis, Biofilm, Irrigation, N-acetylcystein.

(C) 2017 The Authors. Published by Innovare Academic Sciences Pvt Ltd. This is an open access article under the CC BY license (http://creativecommons. org/licenses/by/4. 0/) DOI: http://dx.doi.org/10.22159/ijap.2017.v9s2.05

\section{INTRODUCTION}

Enterococcus faecalis is commonly involved in secondary and persistent endodontic infections. This bacterium has an up to $90 \%$ prevalence in cases of root canal-treated teeth. Root canal-treated teeth are about nine times more likely to harbor E. faecalis than cases with primary infections [1]. E. faecalis bacteria have various genetic forms. They are able to adapt to minimum nutrition conditions and accumulate and produce biofilms. In the root canal system, the essential nutrients and substances needed by the bacteria for metabolism are passed passively through water channels or by electrostatic interactions, trapping these substances inside the biofilms. It is this biofilm that helps other bacteria in the root canal become more resistant to phagocytosis, antibodies, and antibacterial agents [2].

In conditions with minimum oxygen concentration, the bacteria located in the deepest part of the biofilm will experience phenotypic changes associated with their growth rate and gene transcription, which support the survival and virulent characteristics of the bacteria [3]. Studies show longer survivability of some clinical isolates of E. faecalis in pH 12.5 environments compared to E. faecalis ATCC 29212 [4]. In addition, the production of hemolysin in the $E$. faecalis clinical isolates was higher than that of E. faecalis ATCC 29212 [5]. These findings support the presence of characteristic differences between bacteria derived from clinical isolates and ATCC bacteria and illustrate why it is more difficult to eliminate the clinical isolates of E. faecalis than E. faecalis ATCC

Antibacterial agents in the cleaning and shaping procedures of root canal treatments are found in irrigation fluids and medicaments used between visits. Haapasalo found that the irrigation procedure is a key part of a successful root canal treatment as it fulfills several functions, including mechanical, chemical, and microbiological functions. Irrigation is the only way to impact the areas of the root canal that are not touched by mechanical instrumentation, such as oval or narrow root canals, lateral canals, accessory canals, curvatures, irregular root canals, fins, cul-de-sacs, and isthmus. These areas have dead pulp tissues and biofilm residues that can only be removed using irrigation fluid [6]. Chlorhexidine (CHX) at a $2 \%(2 \% \mathrm{CHX})$ concentration is the preferred method for eliminating $E$. faecalis and is often used in irrigation procedures [7]. CHX has an antibacterial effect on both Gram-negative and Gram-positive bacteria and its substantivity properties have a longterm therapeutic effect. However, various concentrations of CHX may cause the apoptosis and necrosis of fibroblast cells, epidermal, dermis, and subcutaneous tissue, and it may decrease the number of osteoblast cells $[8,9]$

Several previous studies have suggested that N-acetylcysteine NAC has an antibacterial effect on endodontic pathogenic bacteria. NAC is not an antibiotic compound, but it is an antioxidant containing thiol groups that effectively reduce the extracellular production of polysaccharides, destroying mature biofilms in the same way as a mucolytic agent and reducing bacterial adhesion [10]. NAC is available in capsules of $200 \mathrm{mg}$ with a $\mathrm{pH}$ of 2.5 and as an injectable/inhalation drug at $100 \mathrm{mg} / \mathrm{ml}$ with a $\mathrm{pH}$ of 7 [11].

NAC is an antioxidant because it plays a role in the donor L-cysteine needed in the synthesis of glutathione (GSH). GSH is an intracellular tripeptide antioxidant that effectively reduces the oxidizing effects of lipids, proteins, and nucleic acids from free radicals, peroxides, and heavy metals [12]. NAC can also increase osteogenesis in bone regeneration [13]. NAC may also prevent tumor necrosis factor- $\alpha$, which may cause L929 fibroblast death [14].

Quah et al. examined NAC as a medicament material and found that NAC is more effective at killing E. faecalis ATCC 29212 in biofilms at concentrations of $50 \mathrm{mg} / \mathrm{ml}$ and a $\mathrm{pH}$ of 11 than calcium hydroxide during a 7-21 days period [15]. Darrag examined NAC's effectiveness as an irrigation material and stated that $200 \mathrm{mg} / \mathrm{ml} \mathrm{NAC}$ is more effective in killing E. faecalis ATCC 29212 and S. mutans ATCC 25175 than $5.25 \%$ $\mathrm{NaOCl}$ and $2 \% \mathrm{CHX}$. This study did not mention the NAC pH value and used a long exposure time of $5 \mathrm{~min}$ [16]. Cindy et al. also found that 
$200 \mathrm{mg} / \mathrm{ml} \mathrm{NAC}$ had a good antibiofilm effect on bacteria in the oral cavity [17].

Based on the different concentrations, $\mathrm{pH}$, and application times used in the previous research, this study will compare the antibacterial potential of $200 \mathrm{mg} / \mathrm{ml} \mathrm{NAC}$ at a pH of 2.5 and a pH of $11(200 \mathrm{mg} / \mathrm{ml}$ NAC pH 2.5 and $200 \mathrm{mg} / \mathrm{ml}$ NAC pH 11, respectively) to that of $2 \%$ CHX on the post-endodontic clinical isolates of the E. faecalis biofilm with 1 min application time identical to that used in clinical irrigation procedures.

\section{METHODS}

The E. faecalis bacteria used in this study were clinical isolate bacteria extracted from non-vital root canals with periapex abnormalities in patients at the Dental Conservation Specialist Hospital of the Dentistry Faculty, University of Indonesia [18]. E. faecalis suspension from the clinical sample culture in the brain heart infusion (BHI) broth was poured into flat bottom 96-well plates. Next, the bacterial suspensions in well plates were incubated at $37^{\circ} \mathrm{C}$ for $24 \mathrm{~h}$ to grow the biofilms.

The $200 \mathrm{mg} / \mathrm{ml}$ NAC pH 2.5 solution was made by dissolving $2 \mathrm{~g}$ NAC in $10 \mathrm{ml}$ distilled water. The $200 \mathrm{mg} / \mathrm{ml} \mathrm{NAC} \mathrm{pH} 11$ solution was made using the titration method, where $2 \mathrm{~g}$ of NAC was being added with sodium hydroxide $(\mathrm{NaOH}) 4 \mathrm{M}$ using a pipette while the solution's $\mathrm{pH}$ change was measured using a pH meter until it reached a $\mathrm{pH}$ of 11 . Distilled water was then added to reach a $10 \mathrm{ml}$ solutions.

After incubation, test materials $(200 \mathrm{mg} / \mathrm{ml} \mathrm{NAC} \mathrm{pH} \mathrm{2.5,200} \mathrm{mg/ml}$ NAC $\mathrm{pH} \mathrm{11}$, and 2\% CHX) were added to the 96-well plates for $1 \mathrm{~min}$. One well plate as a negative control group was added with a sterile saline solution. Then, all plates were drained and rinsed with a Phosphate Buffer Saline (PBS) solution. The biofilms at the bottom of the plate were then scraped with the tip of a pipette and fed into the PBS solution. The biofilms in the PBS solution were diluted up to $5 \mathrm{X}$ and vortexed (mixed using a vortex mixer) for $20 \mathrm{~s}$. Then, the mixture was added to a culture made of BHI agar/gel medium and incubated for $24 \mathrm{~h}$ at $37^{\circ} \mathrm{C}$. The colonies grown in the medium were counted using colony forming units (CFU).

Data on the total number of $E$. faecalis colonies in the culture were analyzed statistically using SPSS 20.0 software. Shapiro-Wilk and homogeneity tests were conducted, followed by a one-way ANOVA test. The post-hoc Bonferroni test was conducted if the one-way ANOVA test yielded a value of $\mathrm{p}<0.05$.

\section{RESULTS}

The number of clinical isolates of E. faecalis colonies may indicate the antibacterial potential of a test material, where fewer colonies indicate greater antibacterial potential. The highest number of $E$. faecalis clinical isolates was found in the $200 \mathrm{mg} / \mathrm{ml}$ NAC pH 2.5 test group (Table 1), i.e., $1128 \mathrm{CFU} / \mathrm{ml}$. This number was still lower than the negative control group, i.e., $1664 \mathrm{CFU} / \mathrm{ml}$.

The lowest mean colony count value was found in the $200 \mathrm{mg} / \mathrm{ml} \mathrm{NAC}$ $\mathrm{pH} 11$ group (752 CFU/ml). Therefore, the $200 \mathrm{mg} / \mathrm{ml} \mathrm{NAC} \mathrm{pH} 11$ group had the greatest antibacterial effect on the E. faecalis clinical isolates biofilm. The number of $E$. faecalis clinical isolates colonies in the $2 \%$ CHX group was lower than the number of colonies in the $200 \mathrm{mg} / \mathrm{ml}$ NAC pH 2.5 group, but the number of colonies was still higher in the $2 \%$ CHX group than the number found in the $200 \mathrm{mg} / \mathrm{ml} \mathrm{NAC} \mathrm{pH} 11$ group. The table also shows that at least two groups had a statistically significant different colony count $(\mathrm{p}<0.05)$.

The post-hoc analysis in Table 2 shows a statistically significant difference in the antibacterial effects of the NAC $\mathrm{pH} 2.5$ groups and the NAC $\mathrm{pH} 11$ group ( $\mathrm{p}=0.009)$.

Similarly, the NAC pH 11 and 2\% CHX groups had statistically significant differences in their colony counts $(\mathrm{p}=0.018)$.
Table 1: Average number of the antibacterial effect on the clinical isolates of the $\mathrm{E}$. faecalis biofilm $(\mathrm{CFU} / \mathrm{ml})$

\begin{tabular}{llll}
\hline Test group & $\mathbf{n}$ & $\begin{array}{l}\text { Average number of } \\
\text { colonies } \pm \text { SD }\end{array}$ & Value of $\mathbf{p}$ \\
\hline $200 \mathrm{mg} / \mathrm{ml} \mathrm{NAC} \mathrm{pH} 2.5$ & 3 & $1128 \pm 82$ & \\
$200 \mathrm{mg} / \mathrm{ml} \mathrm{NAC} \mathrm{pH} 11$ & 3 & $752 \pm 22$ & \\
$2 \% \mathrm{CHX}$ & 3 & $1078 \pm 44$ & $0.006 \bullet$ \\
\hline
\end{tabular}

-Test one-way ANOVA, p<0.05. CFU: Colony forming units, SD: Standard deviation, E. faecalis: Enterococcus faecalis

Table 2: Significant values of the clinical isolate of the $\boldsymbol{E}$. faecalis among the $200 \mathrm{mg} / \mathrm{ml} \mathrm{NAC}$ at pH $2.5,200 \mathrm{mg} / \mathrm{ml} \mathrm{NAC}$ at pH 11, and $2 \%$ CHX groups

\begin{tabular}{llll}
\hline & NAC pH 2.5 & NAC pH 11 & CHX 2\% \\
\hline NAC pH 2.5 & - & $0.009 \bullet$ & 1.000 \\
NAC pH 11 & $0.009 \bullet$ & - & 0.018 \\
2\% CHX & 1.000 & $0.018 \bullet$ & - \\
\hline
\end{tabular}

-Test post-hoc bonferroni, p<0.05. E. faecalis: Enterococcus faecalis, CHX: Chlorhexidine

\section{DISCUSSION}

Clinical isolates of E. faecalis bacteria are believed to be more representative of persistent bacteria in root canals than $E$. faecalis ATCC cultures that have been grown in environmentally and nutritionally adjusted conditions [4]. E. faecalis can grow and produce biofilms in various media, including polystyrene and PVC. The E. faecalis biofilm in this study was grown in 96-well plates, which are flat-bottomed, cylindrical containers made of polystyrene. These well plates can be used to form static biofilms that are similar to biofilms formed in the root canal, which is a closed environment, not a dynamic system, such as the environment surrounded by the bloodstream. The biofilms formed on well plates also share the same characteristics as mature biofilms, which are tolerant to antibiotics and resistant to the immune system [19].

After their formation, the biofilms in this study were exposed to antibacterial agents for $1 \mathrm{~min}$; this is the exact irrigation time a sonic machine uses [20].

This study used $200 \mathrm{mg} / \mathrm{ml} \mathrm{NAC} \mathrm{at} \mathrm{a} \mathrm{pH}$ of 2.5 , which is readily available in the form of capsules, in accordance with Cindy et al. and Darrag. The $200 \mathrm{mg} / \mathrm{ml} \mathrm{NAC} \mathrm{pH} 2.5$ treatment was compared with $200 \mathrm{mg} / \mathrm{ml} \mathrm{NAC}$ with a pH of 11. PH 11 was chosen based on Quah et al., who found it to be a more effective $\mathrm{pH}$ for the NAC than lower $\mathrm{pH}$ levels. The study also used $2 \% \mathrm{CHX}$ as a positive control because it is the preferred antibacterial agent and is commonly used in irrigation procedures in cases of persistent endodontic infection.

The different antibacterial capabilities of these three materials are described in research conducted by Quah et al. The NAC pH 2.5 and NAC pH 11 test groups had statistically significant differences in their colony counts. The comparison of these two groups clearly showed the effect of $\mathrm{pH}$ changes on the antibacterial potential of NAC because NAC pH 11 had higher antibacterial potential than NAC pH 2.5 .

Thiol groups have a sulfur and a hydrogen atom attached by a strong covalent bond. When the NAC $\mathrm{pH}$ is increased through the addition of $\mathrm{NaOH}$, the hydroxyl group $(-\mathrm{H})$ derived from $\mathrm{NaOH}$ releases the covalent bond and produces a reactive thiolate anion (-S-). This thiolate anion is more effective in breaking the protein disulfide bond in the biofilm. The breakdown of the disulfide bond in the three-dimensional structure of the E. faecalis clinical isolate biofilm facilitates and makes it easier for the active agent NAC to bind with the thiol-disulfide groups of bacteria in the biofilm, which may lead to the intermolecular and intramolecular destruction of both the bacterial wall protein and the 
molecules produced by the bacteria. It will also affect the virulence of the E. faecalis clinical isolate bacteria.

In this study, when NAC pH 2.5 was also compared with $2 \%$ CHX. However, the results did not support the research conducted by Darrag since the antibacterial potential of NAC pH 2.5 was lower than that of $2 \%$ CHX. This difference in outcomes may be due to the different research methodology used, such as the difference between the exposure times in each study. Darrag found that the antibacterial potential of $200 \mathrm{mg} / \mathrm{ml} \mathrm{NAC} \mathrm{pH} 2.5$ was greater than the CHX when an exposure time of 5 min was used, which may indicate that thiol groups in the $200 \mathrm{mg} / \mathrm{ml} \mathrm{NAC} \mathrm{pH} 2.5$ require a longer time to break down the disulfide bonds in the biofilm proteins than the electrostatic velocity of the positive charge of CHX to bind to the negative surface of the bacteria through water channel biofilms. However, the difference was not statistically significant.

The low number of colonies remaining in the NAC pH 11 group compared to the $2 \%$ CHX group indicates that the antibacterial potential of NAC pH 11 was greater than that of 2\% CHX, which supports the research of Quah et al. NAC's ability to directly damage the three-dimensional structure of the biofilm enables the antibacterial to more easily penetrate the biofilm and damage the intermolecular and intramolecular bacterial wall proteins. CHX's antibacterial effect is the result of cytoplasmic precipitation. In 1 min treatment, the CHX molecules were able to bind electrostatically to the bacterial wall through the biofilm water channel, but the reaction speed is lower and it damages the structure of the biofilm differently than NAC pH 11.

\section{CONCLUSION}

NAC has antibacterial potential against $E$. faecalis clinical isolates biofilm. The antibacterial potential of $200 \mathrm{mg} / \mathrm{ml} \mathrm{NAC} \mathrm{pH} 11$ is greater than that of $200 \mathrm{mg} / \mathrm{ml} \mathrm{NAC} \mathrm{pH} 2.5$ and $2 \%$ CHX, whereas $200 \mathrm{mg} / \mathrm{ml}$ NAC pH 2.5 and $2 \%$ CHX have the same antibacterial potential.

\section{ACKNOWLEDGMENT}

The publication of this manuscript was supported by Universitas Indonesia.

\section{REFERENCES}

1. Teles AM, Manso MC, Loureiro S, Pina C, Cabeda J. Microorganisms: The reason to perform endodontics. In: Microbial Pathogens and Strategies for Combating them: Science, Technology and Education. Badajoz: Formatex Research Center; 2013. p. 1778-86

2. Baumgartner JC, Siqueira JF, Christine MS, Kishen A. Microbiology of endodontic disease. In: Ingle JI, Bakland LK, Baumgartner JC, editors. Ingle's Endodontics. $6^{\text {th }}$ ed. Shelton: People's Medical Publishing House; 2008. p. 221-308.
3. Saber Sel-D, El-Hady SA. Development of an intracanal mature Enterococcus faecalis biofilm and its susceptibility to some antimicrobial intracanal medications; An in vitro study. Eur J Dent 2012;6:43-50

4. Weckwerth PH, Zapata RO, Vivan RR, Tanomaru Filho M, Maliza AG, Duarte MA. In vitro alkaline $\mathrm{pH}$ resistance of Enterococcus faecalis. Braz Dent J 2013;24:474-6.

5. Fernandes SC, Dhanashree B. Drug resistance and virulence determinants in clinical isolates of Enterococcus species. Indian J Med Res 2013;137:981-5

6. Haapasalo M, Shen Y, Qian W, Gao Y. Irrigation in endodontics. Dent Clin North Am 2010;54:291-312.

7. Chandrappa PM, Dupper A, Tripathi P, Arroju R, Sharma P, Sulochana K. Antimicrobial activity of herbal medicines (tulsi extract, neem extract) and CHX against Enterococcus faecalis in endodontics: An in vitro study. J Int Soc Prev Community Dent 2015;5 Suppl 2:S89-92.

8. Faria G, Cardoso CR, Larson RE, Silva JS, Rossi MA. CHX-induced apoptosis or necrosis in L929 fibroblasts: A role for endoplasmic reticulum stress. Toxicol Appl Pharmacol 2009;234:256-65.

9. Vörös P, Dobrindt O, Perka C, Windisch C, Matziolis G, Röhner E. Human osteoblast damage after antiseptic treatment. Int Orthop 2014;38:177-82.

10. Makipour K, Friedenberg FK. The potential role of N-acetylcysteine for the treatment of Helicobacter pylori. J Clin Gastroenterol 2011;45:841-3.

11. POM D. Farmakope Indonesia. IV. Jakarta: Departemen Kesehatan R.I; 1995. p. 176-7.

12. Casanova T, Garigliany M. N-acetylcysteine: An old drug with variable anti-influenza properties. J Controv Biomed Res 2016;2:1-8.

13. Yamada M, Tsukimura N, Ikeda T, Sugita Y, Att W, Kojima N, et al. $\mathrm{N}$-acetyl cysteine as an osteogenesis-enhancing molecule for bone regeneration. Biomaterials 2013;34:6147-56

14. Mayer M, Noble M. N-acetyl-L-cysteine is a pluripotent protector against cell death and enhancer of trophic factor-mediated cell survival in vitro. Proc Natl Acad Sci U S A 1994;91:7496-500.

15. Quah SY, Wu S, Lui JN, Sum CP, Tan KS. N-acetylcysteine inhibits growth and eradicates biofilm of Enterococcus faecalis. J Endod 2012;38:81-5

16. Darrag AM. Antimicrobial efficacy of endodontic irrigation solutions against planktonic microorganisms and dual-species biofilm. Tanta Dent J 2013;10:129-37.

17. Cindy H, Rene H, Sergio G, Diana R. Rifampicin and N-acteylcisteyne inhibit oral bacterial growth and biofilm formation. Pharm Innov J 2013;2:16-23

18. Ayu NP, Bachtiar BM, Akbar SS, Victor A. Quantitative real-time PCR of cps Type 1,2 and 5 of Enterococcus faecalis and Candida albicans isolated from infected root canal of subject requiring edodontic treatment. J Int Dent Med Res 2016;9:157-63.

19. Kwasny SM, Opperman TJ. Static biofilm cultures of Gram-positive pathogens grown in a microtiter format used for anti-biofilm drug discovery. Curr Protoc Pharmacol 2010; Chapter 13:Unit 13A.8.

20. Uroz-Torres D, González-Rodríguez MP, Ferrer-Luque CM. Effectiveness of the endoactivator system in removing the smear layer after root canal instrumentation. J Endod 2010;36:308-11. 